\title{
Factors affecting byssus attachment in juvenile scallops, Pecten maximus
}

(L.)

Galley, Thomas; Beaumont, Andrew; Le Vay, Lewis; King, Jonathan

\section{Aquaculture}

DOI:

10.1016/j.aquaculture.2020.735504

Published: 15/11/2020

Peer reviewed version

Cyswllt i'r cyhoeddiad / Link to publication

Dyfyniad o'r fersiwn a gyhoeddwyd / Citation for published version (APA):

Galley, T., Beaumont, A., Le Vay, L., \& King, J. (2020). Factors affecting byssus attachment in juvenile scallops, Pecten maximus (L.). Aquaculture, 528, [735504].

https://doi.org/10.1016/j.aquaculture.2020.735504

\footnotetext{
Hawliau Cyffredinol / General rights

Copyright and moral rights for the publications made accessible in the public portal are retained by the authors and/or other copyright owners and it is a condition of accessing publications that users recognise and abide by the legal requirements associated with these rights.

- Users may download and print one copy of any publication from the public portal for the purpose of private study or research.

- You may not further distribute the material or use it for any profit-making activity or commercial gain

- You may freely distribute the URL identifying the publication in the public portal ?
}

Take down policy

If you believe that this document breaches copyright please contact us providing details, and we will remove access to the work immediately and investigate your claim. 


\section{Journal Pre-proof}

Factors affecting byssus attachment in juvenile scallops, Pecten maximus (L.)

Thomas H. Galley, Andy R. Beaumont, Lewis Le Vay, Jonathan W. King

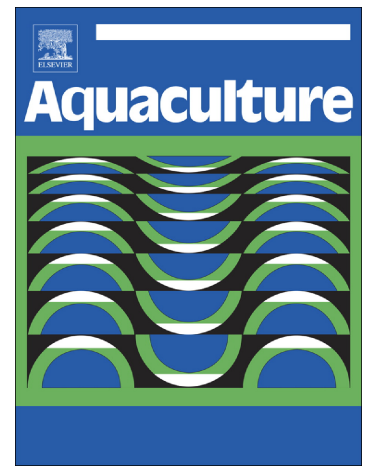

PII: S0044-8486(19)32354-3

DOI: https://doi.org/10.1016/j.aquaculture.2020.735504

Reference:

AQUA 735504

To appear in:

Aquaculture

Received date:

23 September 2019

Revised date:

18 May 2020

Accepted date:

18 May 2020

Please cite this article as: T.H. Galley, A.R. Beaumont, L. Le Vay, et al., Factors affecting byssus attachment in juvenile scallops, Pecten maximus (L.), Aquaculture (2020), https://doi.org/10.1016/j.aquaculture.2020.735504

This is a PDF file of an article that has undergone enhancements after acceptance, such as the addition of a cover page and metadata, and formatting for readability, but it is not yet the definitive version of record. This version will undergo additional copyediting, typesetting and review before it is published in its final form, but we are providing this version to give early visibility of the article. Please note that, during the production process, errors may be discovered which could affect the content, and all legal disclaimers that apply to the journal pertain.

(C) 2020 Published by Elsevier. 
Title

Factors affecting byssus attachment in juvenile scallops, Pecten maximus (L.)

Authors

Thomas H. Galley*, Andy R. Beaumont, Lewis Le Vay, Jonathan W. King

Affiliations: Centre for Applied MarineSciences, School of Ocean Sciences, College of Environmental Sciences and Engineering, Bangor University, Menai Bridge, Anglesey LL595AB, UK.

*Corresponding Author: Centre for Applied Marine Sciences, School of Ocean Sciences, College of Environmental Sciences and Engineering, Bangor University, Menai Bridge, Anglesey LL59 5AB, UK, Tel: (44) (0)1248 382900, e-mail:t.h.galley@bangor.ac.uk 


\section{Abstract}

Environmental and husbandry factors play key roles in the control of byssus attachment and detachment in many bivalve species. Identifying and understanding the impact of influential factors is essential for the management of post-settlement hatchery reared juveniles in species, such as the scallop Pecten maximus. We assessed the impact of substrate type and condition, and attachment period on attachment of juvenile scallops between 1.9 and $5.9 \mathrm{~mm}$ in shell height. Comparison of a variety of substrates showed that scallop juveniles have a preference for textured hard surfaces, with mean attachment up to $75.6 \pm 14.4 \%$ after 24 hours on riven slate in static conditions. Attachment could be significantly increased by preconditioning substrates in flow-through tanks of unfiltered seawater and by having undisturbed attachment periods longer than 1 hour. The effect of substrate type and substrate condition on retention of seed was assessed in a flume. For all substrates, retention decreased with increasing water velocity. However, of the substrates examined (wool, nylon and slate), retention was greatest on the riven slate, with attachment up to $100 \%$ at water flow of $12.6 \pm 0.2 \mathrm{~cm} \mathrm{~second}^{-1}$, although this was not statistically greater than on wool or nylon. Across all substrates preconditioning by immersion in seawater for two weeks significantly compromised juvenile retention at higher water velocities. Based on these findings, recommended parameters for maximising juvenile P. maximus attachment and retention in water velocities up to $12.6 \pm 0.2 \mathrm{~cm}$ second $^{-1}$ include utilising a riven slate type hard substrate, preconditioned for 1 week, with juveniles allowed to attach for 24 hours.

Statement of Relevance

This study provides important advances in our understanding of the influence of different husbandry and environmental conditions on promoting attachment and retention of Pecten maximus juveniles in the hatchery and on-growing environment.

This innovative study examined the impact of novel substrate materials, substrate preconditioning, attachment period and water velocity, all variables that impact upon juvenile scallop attachment.

Following assessment, we offer specific recommendations for promoting attachment and retention of juveniles of the scallop P. maximus. 


\section{Keywords}

Attachment, Substrate, Water Velocity, Pecten maximus

\section{Abbreviations}

FSW $1 \mu \mathrm{m}$ filtered, UV-light irradiated seawater

Umax Maximum water velocity

Uav Depth-average watervelocity

$U^{*} \quad$ Shearvelocity 


\section{Introduction}

The king scallop Pecten maximus, like most pectinid scallops, begins their settlement stage attached by thin byssal threads to benthic surfaces, enabling them to withstand hydrodynamic pressures and avoid dislodgement from their chosen environment (Beninger and Le Pennec, 1991; Brand, 1991; Minchin, 1992). It has been demonstrated in bivalves that byssus production, strength and attachment are affected by environmental conditions (van Winkle, 1970; Allen et al., 1976; Paul, 1980a,b; Young, 1985; Dolmer and Svane, 1994; Pearce and Bourget, 1996; Christophersen and Strand, 2003; Carton et al., 2007; Babarro et al., 2008; Lachance et al., 2008; Ank et al., 2009; Brenner and Buck, 2010; Gagné et al., 2012). Detachment has been associated with exposure to sub-optimal and stressful conditions (Carton et al., 2007), and has been linked to secondary dispersal behaviour, including pedal crawling and byssal drifting (Roper et al., 1995; Lundquist et al., 2004).

Attachment is restricted to early juvenile $P$. maximus, with most remaining attached up to $4-13 \mathrm{~mm}$ in shell length, and few remaining attached once they reach 15mm (Brand, 1991; Minchin, 1992). Previous studies in pectinids associate rapid attachment, and high and stable attachment with high growth and survival (Paul, 1980a,b; Christophersen and Strand, 2003). In pectinids, including $P$. maximus, key factors affecting byssus attachment include salinity (Paul, 1980a; Heasman et al., 1994; Christophersen and Strand, 2003), temperature (Paul, 1980b; Christophersen and Strand, 2003), air exposure, chemical irritants, and pH (Heasman et al., 1994), as well as periods of attachment opportunity, nutrition and shear velocity (Gagné et al., 2012).

Importantly, post-metamorphic locomotion in P. maximus is not restricted to unattached juveniles and adults, with early post-larvae plantigrades alternating between periods of attachment and periods of pedal crawling (Gruffydd and Beaumont, 1972). Small juveniles ( $<500 \mu \mathrm{m}$ in shell length) can employ byssal drifting, (Sigurdsson et al., 1976; Lane et al., 1985; Beaumont and Barnes, 1992), whilst juveniles as small as $3 \mathrm{~mm}$, but usually greater than $5 \mathrm{~mm}$, actively swim or jump by ejecting water from the mantle cavity to propel themselves through the water column.

There has been considerable research and commercial development of aquaculture of $P$. maximus in several European countries (Robert and Nicholas, 2000; Bergh and Strand, 2001; Spencer, 2002; Torkildsen and Magnesen, 2004; Andersen et al., 2011; Strand et al., 2016). The culture of $P$. maximus typically involves collecting or settling spat on a variety of materials, either in the wild or in the hatchery (Brand et al., 1980; Paul et al., 1981; Magnesen and Christophersen, 2007). Plastic 
mesh bags filled with plastic and nylon material have been used as spat collectors, incorporating Netlon and polyethylene bags (Brand et al., 1980; Paul et al., 1981). Whilst in the hatchery and laboratory nylon mesh (Millican, 1997) and PVC surfaces (Gagné et al., 2012) have proven suitable attachment materials. However, there is a need for better understanding of the effect of environmental conditions on byssal attachment and detachment in juveniles. Animals that are attaching, detaching or actively dispersing are diverting val uable resources away from somatic growth. Furthermore, both wild collected and cultured spat typically have to be detached from initial settlement materials, before being transfer to new equipment, such as mesh trays and pearl nets for subsequent culture stages (Millican, 1997; Andersen et al., 2011), therefore promotion of re-attachment could be important. Understanding how environmental and husbandry factors affect seed, both in terms of attachment and retention, will allow effective management strategies to be adopted in hatcheries, supporting the improvement of scallop culture by innovating appropriate juvenile nursery systems (Andersen et al., 2011).

In this study we examined the influence of different husbandry and environmental conditions on promoting attachment and retention of $P$. maximus seed animals. Specific goals included; (1) to assess the impact of variables likely to affect seed attachment in a hatchery environment, including previously untested substrate materials, substrate pre-condition, and attachment period, and (2) to measure the impact of water flow velocity on the level of seed detachment and retention, including the interaction between velocity and other conditions.

\section{Materials and Methods}

Scallop larval culture

Veliger larval P. maximus ( $202 \pm 19 \mu \mathrm{m}$ in shell length) were obtained from the Scal pro AS hatchery (Rong, Norway). These were checked to determine quantity and condition, based upon survival, before stocking at a density of 5 larvae $\mathrm{ml}^{-1}$ in 65 -litre static polyethylene tanks. Tanks were operated as static batch systems, filled to a volume of up to 45 litres with $1 \mu \mathrm{m}$ filtered, UV-light irradiated seawater (FSW), at a salinity of 33\%. Seawater was pumped from the Menai Strait, through two sets of settlement tanks before being subjected to fine filtration using GE hytrex filter cartridges and irradiation with a 110W Commercial UV steriliser. Culture temperature was maintained at $16 \pm 1^{\circ} \mathrm{C}$. Three times a week the larvae were sieved onto a $45 \mu \mathrm{m}$ mesh screen and inspected, and the containers cleaned before the larvae were restocked. Larvae were fed with a 
mixed microalgal diet equivalent to 30 cells $\mathrm{l}^{-1} \mathrm{day}^{-1}$, consisting of Pavlova lutheri (PLY75), Isochrysis sp. (clone T-ISO) (PLY506A) and Chaetoceros calcitrans (PLY537) at a cell ratio of 1:1:1. Larvae were reared in this system for up to 20 days following arrival, before transfer to a juvenile downwelling culture system.

Downwelling culture system

Juvenile scallops were maintained in cylindrical sieves ( $160 \mathrm{~mm}$ dia.) with mesh sizes ranging from an initial $85 \mu \mathrm{m}$ up to $500 \mu \mathrm{m}$, with mesh size increasing in line with scallop growth. Sieves were connected to a narrow 23-litre central tank suspended in a larger 120-litre reservoir tank. Water was pumped from the reservoir to the central tank, which flowed back to the reservoir through the sieves. The system was supplied with a constant seawater inflow $\left(0.28 \pm 0.06\right.$ litres minute $\left.^{-1}\right)$ filtered using GE hytrex filter cartridges to $10 \mu \mathrm{m}$. The system was maintained at ambient temperature, ranging from 10 to $20^{\circ} \mathrm{C}$. Juvenile scallops were fed a mixture of microalgae daily, consisting of $P$. lutheri, Isochrysis sp., C. calcitrans, Rhinomonas reticulata (CCAP 995/2), and Tetraselmis chuii (CCAP 8/6) ab libitum.

Standardised juvenile pre-experimental regime

Prior to commencing experiments, a proportion of juveniles were removed from the downwelling culture system and maintained for 6 days under a controlled and standardised husbandry regime in order to ensure a comparable starting condition of animals used in the study. Juveniles were stocked at a density of $1.0 \mathrm{~g}$ (wet weight), in static tanks of FSW, and maintained at a temperature of $12 \pm 1^{\circ} \mathrm{C}$. Tanks were aerated and $100 \%$ water changes conducted every $2-3$ days. Juveniles were

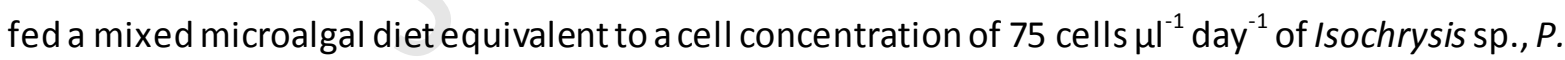
lutheri and C. calcitrans, at a cell ratio of 1:1:1. Measurements of shell height were made to determine the experimental size range after juvenile conditioning. Digital images of juveniles were taken using a Canon EOS 1000D, and images measured using Image J software.

Juvenile attachment to substrate types over time

A range of materials were compared, including hard surfaces such as smooth glass and textured slate, and soft natural fibrous materials, as well as nylon mesh. Experimental parameters for all experiments are summarised in Table 1. All substrates were formed into small tiles: Glass tiles were 
from standard glazing panes and slate from riven roofing tiles, whilst all fabric substrates were wrapped round a core of slate to provide a rigid, negatively buoyant structure. In all experiments, juveniles were stocked at $0.5 \pm 0.05 \mathrm{~cm}^{-2}$ directly onto the substrates in static dishes filled with FSW. Water temperature was maintained at $12 \pm 1^{\circ} \mathrm{C}$ and attachment dishes were fed as described for conditioning. Juveniles were added to dishes and left undisturbed for an attachment periods of 1 or 24 hours, under constant illumination. Substrates were gently rinsed to remove any unattached juveniles and attachment percentage determined from counts of attached juveniles. In all experiments scallop juveniles of $<13 \mathrm{~mm}$ shell length were used (Table 1 ), as this is within the size range when attachment is known to occur (Brand, 1991; Minchin, 1992)

Effect of preconditioning substrates on juvenile attachment and retention

Following the same method, juvenile attachment was compared on substrates preconditioned for 0 , 1 and 2 weeks in a flow-through tank, supplied with seawater pumped from the Menai Strait, through two sets of settlement tanks but without additional filtration. The substrate preconditioning tank was a 120 -litre polypropylene tank maintained at $12 \pm 1^{\circ} \mathrm{C}$ and supplied with an inflow of approximately $0.42 \pm 0.12$ litres minute ${ }^{-1}$, equating to a residence time ranging from 3 hours 42 minutes to 6 hours 40 minutes. In addition, detachment of juvenile scallops was examined in a laminar flow re-circulating benthic flume (Figure 1) at velocities up to $12.6 \pm 0.2 \mathrm{~cm} \mathrm{~second}^{-1}$. The flume consisted of a $4 \mathrm{~m}$ long $\times 0.4 \mathrm{~m}$ wide fibre glass raceway tank with PVC bottom plate with nine $5.5 \times 5.5 \mathrm{~cm}$ depressions to hold substrate tiles in a $3 \times 3$ configuration (Figure $2-$ see Supplementary Material for full description).

The flume was filled with $1 \mu \mathrm{m}$ filtered seawater to a constant depth of $5 \mathrm{~cm}$, with an approximate total volume of 90 litres. Water temperature was maintained at $12 \pm 1^{\circ} \mathrm{C}$ and experiments were carried out in constant illumination. Velocity profiles were measured prior to running experiments (see Supplementary Material) and expressed as mean maximum ( \pm standard deviation) water velocity (mean Umax) across the various substrate types. As an initial control, passive retention of unattached juveniles placed directly on the substrates within the flume was tested over a range of mean maximum water velocities, for 10 minutes at each velocity. Thereafter, substrates with attached juveniles were transferred from the settlement dishes and the tests repeated. In all flume experiments retention was quantified from counts of juveniles at the beginning and end of each velocity period, with dispersed individuals removed. 
Table 1: Summary of experimental parameters.

\begin{tabular}{|c|c|c|c|c|}
\hline Experiment & $\begin{array}{l}\text { Response } \\
\text { variable }\end{array}$ & Environmental variables & $\begin{array}{l}\text { Treatment } \\
\text { replicates }\end{array}$ & $\begin{array}{c}\text { Shell height of } \\
\text { juveniles scallops } \\
\text { post- standardisation } \\
(\mathrm{mm})\end{array}$ \\
\hline $\begin{array}{c}\text { Juvenile } \\
\text { attachment to } \\
\text { substrate types } \\
\text { over time }\end{array}$ & $\begin{array}{c}\% \\
\text { Attachment }\end{array}$ & $\begin{array}{l}\text { - Substrates: } \\
\text { Glass }(50.4 \times 50.2 \times 3.9 \mathrm{~mm}-\mathrm{w} \times \mathrm{I} \times \mathrm{h}) \\
\text { Slate }(50.6 \times 50.6 \times 3.5 \mathrm{~mm}) \\
\text { Nylon mesh }(53.9 \times 53.9 \times 1.5 \mathrm{~mm}- \\
500 \mu \mathrm{m} \text { diameter weave) } \\
\text { Wool }(56.6 \times 56.9 \times 7.4 \mathrm{~mm}) \\
\text { Cotton }(54.3 \times 53.9 \times 5.2 \mathrm{~mm}) \\
\text { Soy fabric }(54.1 \times 53.3 \times 5.1 \mathrm{~mm}) \\
\text { Hemp }(55.4 \times 55.8 \times 4.9 \mathrm{~mm}) \\
\text { Attachment periods: } \\
1 \text { hour, } 24 \text { hours }\end{array}$ & 5 & $\begin{array}{l}\text { Range }=1.9 \text { to } 5.4 \\
(\text { mean } 3.3 \pm 0.8)\end{array}$ \\
\hline $\begin{array}{l}\text { Effect of } \\
\text { preconditioning } \\
\text { substrates }\end{array}$ & $\begin{array}{l}\text { \% } \\
\text { Attachment } \\
\text { \& Retention }\end{array}$ & $\begin{array}{l}\text { - Substrate: } \\
\text { Wool, Slate, Nylon } \\
\text { - Substrate Pre-condition: } \\
0,1,2 \text { weeks } \\
\text { - Water velocity }\left(\mathrm{cm} \mathrm{second}^{-1}\right) \text { : } \\
0.0,7.2 \pm 0.1,10.1 \pm 0.2,12.2 \pm 0.1,12.6 \\
\pm 0.2\end{array}$ & 3 & $\begin{array}{c}\text { Range }=1.9 \text { to } 5.9 \\
(\text { mean } 4.0 \pm 1.0)\end{array}$ \\
\hline
\end{tabular}

Statistical analyses

All data sets are described as a percentage of attached or retained seed, whilst flume velocities are described as $\mathrm{cm}$ second ${ }^{-1}$. Prior to analysing, all percentage data were converted by arcsine square root transformation. Data presented in all figures is untransformed. Data sets were tested using the Anderson-Darling test to investigate departure from normality and Bartlett's test to assess heteroscedasticity before applying any test of comparison (Sokal and Rohlf, 1995). Two- and threeway ANOVA tests were used, as appropriate, to determine if there was any significant difference in percentage attachment and retention, followed by pairwise comparisons between treatments using Tukey's comparison test. All results were considered to be significantly different when $P<0.05$. Analyses were undertaken using the statistical package Minitab ${ }^{\circledR}$. 


\section{Results}

Juvenile attachment to substrate types over time

The mean percentage attachment of juvenile scallops to seven substrate materials after 1 and 24 hours is shown in Figure 3. The ability of scallops to attach was significantly influenced by both substrate type (ANOVA: F-statistic $=8.80, P=<0.001, D F=1$ ) and length of attachment period (ANOVA: F-statistic $=55.73, P=<0.001, D F=1$ ), although no interaction between the two variables was observed (ANOVA: F-statistic $=1.41, P=0.227, D F=6$ ). Attachment after 1 hour was limited, with significantly greater attachment after 24 hours. Highest attachment was to the slate substrate, which was significantly higher than on most other substrates (Tukey $\mathrm{P}<0.05$ ), with the exception of wool and glass (Tukey $P>0.05$ ) (Figure 3). Attachment was lowest to the cotton substrate, but this difference was only significantly lower than the slate, wool and glass substrates (Tukey $\mathrm{P}<0.05$ ). Attachment to all other substrates was statistically equal (Tukey $P>0.05$ ) (Figure 3 ). The limited significant difference between substrates is likely a consequence of the variable rates in juvenile attachment observed to each substrate type.

Effect of preconditioning substrates on juvenile attachment and retention

Results of the initial control test, showed that both water velocity and substrate type influenced the passive retention of unattached juvenile scallops. Figure 4 shows the percentage decrease of unattached juvenile scallops retained on nylon, slate and wool substrates with increasing water velocities $\left(\mathrm{cm} \mathrm{second}^{-1}\right)$. Retention on all substrates significantly decreased with increasing water velocity (ANOVA: F-statistic $=30.81, P=<0.001, D F=4$ ). Retention at the highest velocity, $12.6 \pm 0.2 \mathrm{~cm} \mathrm{~second}^{-1}$, was significantly lower than all other velocities (Tukey $\mathrm{P}<0.05$ ), except $12.2 \pm 0.1 \mathrm{~cm}$ second $^{-1}$ (Tukey $P>0.05$ ). Retention at all water velocities was significantly lower than in static water (Tukey $\mathrm{P}<0.05$ ), whilst retention at $7.2 \pm 0.1 \mathrm{~cm}$ second ${ }^{-1}$ was significantly higher than at $10.1 \pm 0.2 \mathrm{~cm} \mathrm{~second}^{-1}$, which was approximately equal to $12.2 \pm 0.1 \mathrm{~cm} \mathrm{~second}^{-1}$. There was a significant difference between substrates (ANOVA: F-statistic $=15.74, P=<0.001, D F=2$ ), with significantly more individuals displaced from slate and nylon substrates than from wool (Tukey $P<0.05$ ). There was no difference between slate and nylon (Tukey $P>0.05$ ). There was no significant interaction between water velocity and substrate on the retention of unattached juveniles (ANOVA: F-statistic $=1.73, \mathrm{P}=0.131, \mathrm{DF}=8)$. 
The mean percentage attachment of juvenile scallops (after 24 hours) to slate, wool and nylon preconditioned in seawater for 1 and 2 weeks compared to unconditioned substrates is shown in Figure 5. There was no significant effect of substrate type on attachment of juvenile scallops in this experiment (ANOVA: F-statistic $=0.19, P=0.828, D F=2$ ), however there was a difference between substrate preconditioning treatments (ANOVA: F-statistic $=4.37, P=0.028, D F=2$ ). Attachment to substrates preconditioned for 2 weeks was significantly higher than unconditioned substrates (Tukey $P<0.05$ ). No significant interaction between the variables was observed (ANOVA: F-statistic $=2.00, P$ $=0.138, \mathrm{DF}=4)$.

Figure 6 shows the mean percentage retention of juvenile scallops on slate, wool and nylon substrates preconditioned for 0,1 and 2 weeks under watervelocities up to $12.6 \pm 0.2 \mathrm{~cm}$ second $\mathrm{d}^{-1}$. Analysis showed that the length of substrate preconditioning (ANOVA: F-statistic $=22.52, P=<0.001$, $D F=2$ ) and water velocity (ANOVA: F-statistic $=10.72, P=<0.001, D F=4$ ) significantly influenced juvenile retention, whilst substrate type had no influence (ANOVA: F-statistic $=0.75, P=0.474, D F=$ 2).

Retention of attached juvenile scallops was highest for substrates preconditioned for 1 week, followed by those on unconditioned substrates, (Figure 6). Retention on substrates pre-conditioned for two weeks was significantly lower than on both unconditioned and 1-week preconditioned treatments (Tukey $\mathrm{P}<0.05$ ). Maximum retention was on substrates preconditioned for 1 week, although retention on unconditioned substrates was statistically equal (Tukey $P>0.05$ ). Retention to all substrates decreased with increasing velocity (Figure 6), with highest detachment at the highest velocity $\left(12.6 \pm 0.2 \mathrm{~cm}\right.$ second ${ }^{-1}$ ), significantly higher than at all other velocities (Tukey $P<0.05$ ), except $12.2 \pm 0.1 \mathrm{~cm}$ second ${ }^{-1}$. However, velocities up to $10.1 \pm 0.2 \mathrm{~cm}$ second ${ }^{-1}$ did not result in significantly higher dispersal than static conditions (Tukey P>0.05). Velocities of $7.2 \pm 0.1$ and $10.1 \pm 0.2 \mathrm{~cm}$ second ${ }^{1}$, and $10.1 \pm 0.2$ and $12.2 \pm 0.1 \mathrm{~cm}$ second $^{-1}$ displayed approximately equal retention. A combined effect of substrate preconditioning and water velocity was al so found (ANOVA: F-statistic $=2.36, P=$ 0.024 , DF $=8$ ), as the magnitude of loss from substrates preconditioned for 2 weeks increased at a greater rate with increasing velocity, than from substrates preconditioned for 0 or 1 week, with larger differences observed at $12.2 \pm 0.1 \mathrm{~cm}$ second $^{-1}$ and above. 


\section{Discussion}

Maximising the retention of valuable seed animals is a priority for bivalve a quaculture, however many environmental stimuli have been identified as factors influencing attachment and retention in juvenile bivalves. This study provides important insights into the influence of multiple factors on juveniles of the scallop P. maximus.

\section{Substrate type}

In this study, experimental substrates were not chosen to imitate natural substrates but instead to reflect a range of textures which may prove useful in a hatchery environment. The behaviour of juveniles in relation to their environment and handling is important to future hatchery operations for this species. Notably the slate material used in this study was riven and textured, and therefore more like a natural rock surface, however together with the fibre materials, they were seen as offering substrate options, which were natural, biodegradable in the case of the fibre materials, and alternatives to more traditional plastic based materials. The effectiveness of artificial and natural substrates as sites of bivalve attachment in other species has proven to be dependent upon the properties of the substrate (Pearce and Bourget, 1996; Devakie and Ali, 2002; Ank et al., 2009; Brenner and Buck, 2010). The present study analysed substrate materials offering a range of properties including hard surfaces in the form of smooth glass and textured slate, soft natural fibrous materials, as well as nylon mesh as a representative of the type of material used within the bivalve hatchery industry. Substrate type did influence re-attachment of juvenile $P$. maximus although influence could be inconsistent. From this study slate offers the most suitable attachment substrate, although wool and nylon are also effective substrates. A more suitable and reliable substrate material remains to be identified, although it is likely that other environmental factors act in concert with substrate properties. Orientation and shape of attachment structures have also been suggested as important factors for study (Paul et al., 1981).

In many cases the retention of attached bivalves, is also dependent upon the relationship with hydrodynamic pressures. Previous studies have demonstrated that the influence of substrate properties can be modified by changing water velocities, with incidence of pedal crawling or byssus drifting increasing in conjunction with water velocity (Roper et al., 1995; Lundquist et al., 2004). In flume experiments, Lundquist et al. (2004) demonstrated that juveniles (<8mm in length) of the 
bivalves Macomona liliana and Austrovenus stutchburyi undertook increasing active dispersal behaviour, in response to unsuitable substrate type and increasing flowvelocity.

In the flume experiment with attached juveniles in the present study, detachment increased with watervelocity. Gagné et al. (2012) also demonstrated an increase in dispersal of smaller P. maximus juveniles ( $<1.2$ to $>1.5 \mathrm{~mm}$ in length) with increasing water velocity. In ou r study attached juveniles between 1.9 and $5.9 \mathrm{~mm}$ could resist significant dispersal at Umax velocities up to $10.1 \pm 0.2 \mathrm{~cm}$ second $^{-1}$, at least over short periods, with attachment remaining high at water velocities up to $12.6 \pm 0.2 \mathrm{~cm} \mathrm{~second}^{-1}$. Whilst there was no statistical divergence between substrates, retention was greatest on the riven slate, with mean attachment notably up to $100 \%$ at the highest watervelocity tested. Whilst this is greater than the velocities applied in an on-shore nursery system developed in Norway, fed with natural seawater at a flow rate of 2 to $4 \mathrm{~cm}$ second ${ }^{-1}$ (Magnesen and Christophersen, 2007), it demonstrates that juvenile scallops can remain attached under greater velocities, including those that may be experienced in off-shore systems. It also suggests that flow rates in on-shore systems could be increased, even over short periods of time, in order to increase food availability, preventing potential reductions in juvenile growth due to food depletion (Magnesen and Christophersen, 2007). It is recognised that water velocity affects scallop filtration and feeding behaviour, with excessive velocities leading to stress and growth inhibition. Flow speeds between 0.2 and $6 \mathrm{~cm}$ second ${ }^{-1}$ have been recommended for different species, as reviewed by Magnesen and Christophersen (2007). However, increasing velocities to increase food availability could be possible without necessarily causing detachment and dispersal of juveniles.

This study also implies that there is a mechanical effect of the substrate material, as well as the juvenilescallop's ability to attach and remain attached to the various substrates. In our study under flowing water conditions the test substrates had no influence on mean (Uav) and maximum (Umax) velocities, however there was a profound difference in the estimated shear velocities $\left(U^{*}\right)$ (see Supplementary Material). As expected, the wool substrate had a consistently higher $U^{*}$, approximately twice as high compared to nylon and slate, in line with rougher surfaces having a higher shear velocity (Kirkgöz, 1989). This study showed that substrate properties had a significant impact upon passive juvenile retention, with the increased roughness and complexity of the wool increasing retention of unattached juveniles. Retention of all unattached individuals decreased with increasing water velocity for each substrate, however more individuals were displaced from the slate and nylon substrates than from the wool substrate. At the highest velocity dispersal was on average 
32.8 to $53.7 \%$ lower on wool than on slate and nylon respectively. Therefore, the shear velocities across substrates play a key role in juvenile retention.

\section{Attachment period}

The length of attachment period prior to disturbance also plays a crucial role (Paul, 1980b). Drag forces associated with detachment have been significantly and positively correlated with the duration of attachment in cyprids of the barnacle Balanus Amphitrite (Eckman et al., 1990). In our study attachment after 1 hour was significantly lower than after 24 hours on all tested substrates. In particular attachment increased by over $300 \%$ on slate after 24 hours. This concurs with the study by Gagné et al. (2012) who showed in smaller P. maximus juveniles, ranging from $<1.2$ to $>1.5 \mathrm{~mm}$ in length, higher detachment was observed following an attachment period of just 30 minutes compared to a 12-hour attachment period, when subjected to shear velocities of $1.42 \mathrm{~cm} \mathrm{~second}^{-1}$ and over. The implication for culture activities is that $P$. maximus are slow to form attachments and require sufficient time following detachment, such as when being moved between rearing stages, to reform secure byssus attachment before being subjected to hydrodynamic pressures. Assessment of a wide range of attachment periods could be beneficial to optimise handling protocols.

\section{Surface preconditioning}

In the present study a marginal improvement in attachment on slate and wool was seen with increased length of preconditioning, whilst a dramatic increase was observed between nylon mesh conditioned for 1 week or more over clean unconditioned nylon. Overall preconditioning substrates for 2 weeks significantly improved attachment over clean substrates, whilst preconditioning for 1 week resulted in attachment that was neither significantly higher nor lower than either other treatment. It is accepted that biofilm coverings on substrates serve as an attraction for bivalve settlement (Pearce and Bourget, 1996; Devakie and Ali, 2002), and the properties that act on larval settlement may also trigger a response in older juveniles to some degree. Preconditioning substrates may potentially overcome any deficiencies in the actual substrates, as seen with the nylon substrate in the current study. The present study also showed that substrate preconditioning influences the retention of juvenile animals. In the flume retention was higher, with increasing velocity, on substrates pre-conditioned for 1 week, although this was not significantly higher than unconditioned substrates. In contrast to the results seen for attachment it is clear that preconditioning substrates for too long, i.e. 2 weeks, compromised the mean retention of juvenile $P$. 
maximus to artificial substrates. The shearing away or erosion of biofilms is related to hydrodynamic factors, with material detachment increasing with fluid velocity (Trulear and Characklis, 1982). Therefore, excess biofilm material may not provide a stable attachment structure, with erosion leading to a loss of attachment. In addition, the results also indicate that there is an interaction between substrate precondition and water velocity. This is because not only was the detachment higher from substrates conditioned for 2 weeks, but the magnitude of loss from substrates conditioned for 2 weeks increased at a greater rate with increasing velocity, than on substrates conditioned for 0 or 1 week. The detrimental nature of excess biofilm was magnified with increasing velocity. It is therefore clearly important to establish the impact of substrate condition both on attachment and retention. In this case a moderate conditioning period of 1 week optimises attachment whilst maximising the retention of those that attached. Notably, in the experiment examining the impact of preconditioning, retention on slate conditioned for 1 week was up to $100 \%$ at the highest water velocity tested.

This study examined the impact of a range of culture and environmental factors on the attachment and retention of juvenile P. maximus. It demonstrated that factors including substrate type, substrate preconditioning, attachment period and water velocityall play an important role. Based upon the results, recommended aquaculture practices for maximising the chance of juvenile $P$. maximus attachment and retention in water velocities up to $12.6 \pm 0.2 \mathrm{~cm}$ second ${ }^{-1}$, is to use a riven slate type hard substrate, preconditioned for 1 week, with juveniles allowed to attach for at least 24 hours. The results of this broad study provide additional insight into life stages key to the effective culture and management of this commercially important species. However, it is clear that influential factors should not be considered in isolation, since there can be interaction between multiple variables.

\section{Acknowledgements}

The authors would like to thank Dr Thorolf Magnesen and the Scalpro AS hatchery in Rong, Norway, for supplying the scallops, and Llyn Aquaculture, Wales, for providing the fibreglass raceway used for the flume. We would also like to thank colleagues from the School of Ocean Sciences at Bangor University; Dr Jaco Baas and Dr Jonathan Malarkey for the introduction to and technical support in devising our benthicflume, and its calibration; Gwyn Hughes for microalgal technical support; and Ian Nicholls for the construction of flume components. This research was supported through the EU 
Framework 7 funding programme as part of the project "Research to Improve Production of Seed (REPROSEED)" (Grant No. 245119).

\section{References}

Allen, J.A., Cook, M., Jackson, D.J., Preston, S., Worth, E.M., 1976. Observations on the rate of production and mechanical properties of the byssus threads of Mytilus edulis $\mathrm{L}$. Journal of Molluscan Studies 42: 279-289.

Andersen, S., Christophersen, G., Magnesen, T., 2011. Spat production of the great scallop (Pecten maximus): a roller coaster. Canadian Journal of Zoology 89: 579-598.

Ank, G., Porto, T.F., Pereira, R.C., da Gama, B.A.P., 2009. Effects of different biotic substrata on mussel attachment. Biofouling 25: 173-180.

Babarro, J.M.F., Reiriz M.J.F., Labarta, U., 2008. Secretion of byssal threads and attachment strength of Mytilus galloprovincialis: the influence of size and food availability. Journal of Marine Biological Association of the United Kingdom 88: 783-791.

Beaumont, A.R., Barnes, D.A., 1992. Aspects of veliger larval growth and byssus drifting of the spat of Pecten maximus and Aequipecten (Chlamys) opercularis. ICES Journal of Marine Science 49: 417-423.

Beninger, P.G., Le Pennec, M., 1991. Functional anatomy of scallops. In: S.E. Shumway, ed. Scallops: biology, ecology and aquaculture. Amsterdam: Elsevier Science. pp. 133-223.

Bergh, $\varnothing$., Strand, $\varnothing$., 2001. Great scallop, Pecten maximus, research and culture strategies in Norway: a review. Aquaculture International 9: 305-318.

Brand, A.R., Paul, J.D., Hoogesteger, J.N., 1980. Spat settlement of the scallops Chlamys opercularis (L.) and Pecten maximus (L.) on artificial collectors. Journal of the Marine Biological Association of the United Kingdom 60: 379-390.

Brand, A.R., 1991. Scallop ecology: distributions and behaviour. In: S.E. Shumway, ed. Scallops: biology, ecology and aquaculture. Amsterdam: Elsevier Science. pp. 517-584.

Brenner, M., Buck, B.H., 2010. Attachment properties of blue mussel (Mytilus edulis L.) byssus threads on culture-based artificial collector substrates. Aquacultural Engineering 42: 128-139.

Carton, A.G., Jeffs, A.G., Foote, G., Palmer, H., Bilton, J., 2007. Evaluation of methods for assessing the retention of seed mussels (Perna canaliculus) prior to seeding for grow-out. Aquaculture 262: 521-527.

Christophersen, G., Strand, $\varnothing$., 2003. Effect of reduced salinity on the great scallop (Pecten maximus) spat at two rearing temperatures. Aquaculture 215: 79-92. 
Devakie, M.N., Ali, A.B., 2002. Effective use of plastic sheet as substrate in enhancing tropical oyster (Crassostrea iredalei Faustino) larvae settlement in the hatchery. Aquaculture 212: 277-287.

Dolmer, P., Svane, I., 1994. Attachment and orientation of Mytilus edulis L. in flowing water. Ophelia 40: 63-74.

Eckman, J.E., Savidge, W.B., Gross, T.F., 1990. Relationship between duration of cyprid attachment and drag forces associated with detachment of Balanus amphitrite cyprids. Marine Biology 107: 111-118.

Gagné R., Tremblay R., Oliver, F., Pernet, P.M., Samain, J-F., 2012. Effect of shearvelocity and flow regime on scallop post-larval detachment feed on two different diets. Aquaculture 370-371: 172-178.

Gruffydd, LL.D., Beaumont, A.R., 1972. A method for rearing Pecten maximus larvae in the laboratory. Marine Biology 15: 350-355.

Heasman, M.P., O'Connor, W.A., Frazer, A.W., 1994. Detachment of commercial scallop Pecten fumatus, spat from settlement substrates. Aquaculture 123: 401-407.

Kirkgöz, M.S., 1989. Turbulent velocity profiles for smooth and rough open channel flow. Journal of Hydraulic Engineering 115: 1543-1561.

Lachance, A.A., Myrand, B., Tremblay, R., Koutitonsky, V., Carrington, E., 2008. Biotic and abiotic factors influencing attachment strength of blue mussels Mytilus edulis in suspended culture. Aquatic Biology 2:119-129.

Lane, D.J.W., Beaumont, A.R., Hunter, J.R., 1985. Byssus drifting and the drifting threads of the young post-larval mussel Mytilus edulis. Marine Biology 84: 301-308.

Lundquist, C.J., Pilditch, C.A., Cummings, V.J., 2004. Behaviour controls post-settlement dispersal by the juvenile bivalves Austrovenus stutchburyi and Macomona liliana. Journal of Experimental Marine Biology and Ecology 306: 51-74.

Magnesen, T., Christophersen, G., 2007. Large-scale raceway nursery for improved scallop (Pecten maximus) spat production. Aquacultural Engineering 36: 149-158.

Millican, P.F., 1997. The hatchery rearing of the king scallop (Pectin maximus). Lowestoft: Centre for Environment, Fisheries and Aquaculture Science.

Minchin, D., 1992. Biological observations on young scallops, Pecten maximus. Journal of the Marine Biological Association of the United Kingdom 72: 807-819.

Paul, J.D., 1980a. Salinity-temperature relationships in the queen scallop Chalamys opercularis. Marine Biology 56: 295-300. 
Paul, J.D., 1980b. Upper temperature tolerance and the effects of temperature on byssus attachment in the queen scallop, Chalamys opercularis. Journal of Experimental Maine Biology and Ecology 46: 41-50.

Paul, J.D., Brand, A.R., Hoogesteger, J.N., 1981. Experimental cultivation of the scallops Chlamys opercularis (L.) and Pecten maximus (L.) using naturally produced spat. Aquaculture 24: 31-44.

Pearce, C.M., Bourget, E., 1996. Settlement of larvae of the giant scallop, Placopecten magellanicus (Gmelin), on various artificial and natural substrata under hatchery-type conditions. Aquaculture 141: 201-221.

Robert, R., Nicolas, L., 2000. The effect of seawater flow and temperature on metamorphosis and postlarval development in great scallop. Aquaculture International 8: 513-530.

Roper, D.S., Nipper, M.G., Hickey C.W., Martin, M.L., Weatherhead, M.A., 1995. Burial, crawling and drifting behaviour of the bivalve Macomona liliana in response to common sediment contaminants. Marine Pollution Bulletin 31:471-478.

Sigurdsson, J.B., Titman, C.W., Davies, P.A., 1976. The dispersal of young post-larval bivalve molluscs by byssus threads. Nature 262: 386-387.

Sokal, R.R., Rohlf, F.J., 1995. Biometry: The principles and practice of statistics in biological research. Third ed. New York: Freeman.

Spencer, B.E., 2002. Molluscan shellfish farming. Oxford: Blackwell Science.

Strand, Ø., Louro, A., Duncan, P.F., 2016. European Aquaculture. In: S.E. Shumway and G. Jay Parsons, eds., Scallops: Biology, Ecology, Aquaculture and Fisheries. Oxford: Elsevier Science. pp. 859-890.

Torkildsen, L., Magnesen, T., 2004. Hatchery production of scallop larvae (Pecten maximus) survival in different rearing systems. Aquaculture International 12: 489-507.

Trulear, M.G., Characklis, W.G., 1982. Dynamics of biofilm processes. Journal (Water Pollution Control Federation) 54: 1288-1301.

van Winkle Jr., W., 1970. Effect of environmental factors on byssal thread formation. Marine Biology 7: 143-148.

Young, G, A., 1985. Byssus-thread formation by the mussel Mytilus edulis: effects of environmental factors. Marine Ecology Progress Series 24: 261-271. 


\section{List of Figure Legends}

Figure 1: Diagram of the benthic flume constructed to test the influence of water velocity on juvenile scallops.

Figure 2: Plan view of the substrate section of the flume $($ scalein $\mathrm{cm})$.

Figure 3: Mean percentage attachment ( \pm standard deviation) of juvenile Pecten maximus to seven different substrates over attachment periods of 1 and 24 hours.

Figure 4: Mean percentage retention ( \pm standard deviation) of unattached juvenile scallops on wool, slate and nylon substrates set in a benthic water flume over a series of increasing water velocities, following exposure for 10 minutes at each velocity.

Figure 5: Mean percentage attachment after 24 hours ( \pm standard deviation) of juvenile Pecten maximus on wool, slate and nylon substrates preconditioned in seawater for 0,1 and 2 weeks.

Figure 6: Mean percentage retention ( \pm standard deviation) of attached juvenile scallops on wool, slate and nylon substrates preconditioned in seawater for 0,1 or 2 weeks, over a series of increasing water velocities, following exposure for 10 minutes at each velocity. 
Conflict of Interest: None

Highlights

- We assessed the effect of environmental and husbandry factors on the attachment and retention of juvenile Pecten maximus.

- Maximum attachment of juvenilescallops was on a textured hard surface, with mean attachment up to $75.6 \pm 14.4 \%$ after 24 hours on riven slate. Attachment could be increased by preconditioning substrates and by having undisturbed attachment periods longer than 1 hour.

- Retention of attached juveniles decreased with increasing water velocity, up to a maximum tested velocity of $12.6 \pm 0.2 \mathrm{~cm}^{\text {second }}{ }^{-1}$.

- There was no statistical difference in juvenile scallop retention on wool, nylon and slate substrates in flowing water conditions. However, it was greatest on riven slate, with retention up to $100 \%$ at water velocities of $12.6 \pm 0.2 \mathrm{~cm} \mathrm{~second}^{-1}$. Preconditioning substrates influenced retention, with lower retention following substrate preconditioning for 2 weeks.

- Recommended parameters for maximising attachment and retention in water velocities up to $12.6 \pm 0.2 \mathrm{~cm}$ second ${ }^{-1}$ are to use a riven slate type hard substrate, preconditioned for 1 week, and to allow juveniles to attach for 24 hours. 


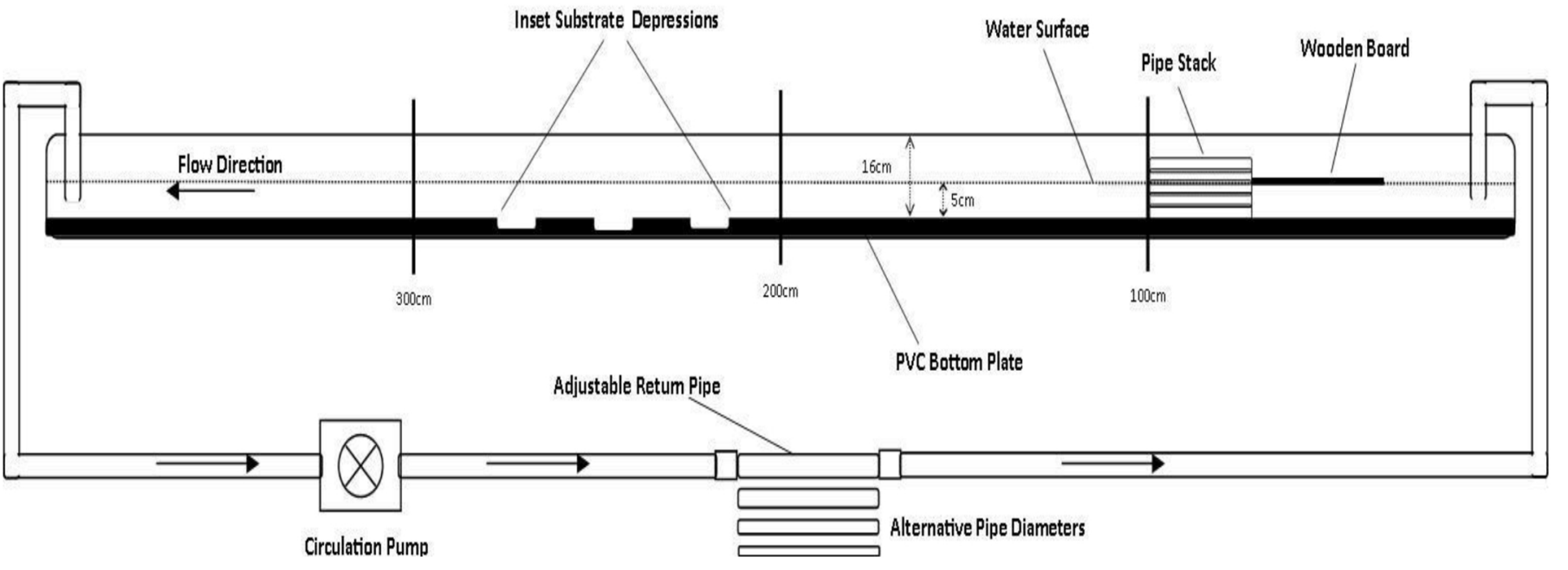

Figure 1 
Substrate depressions

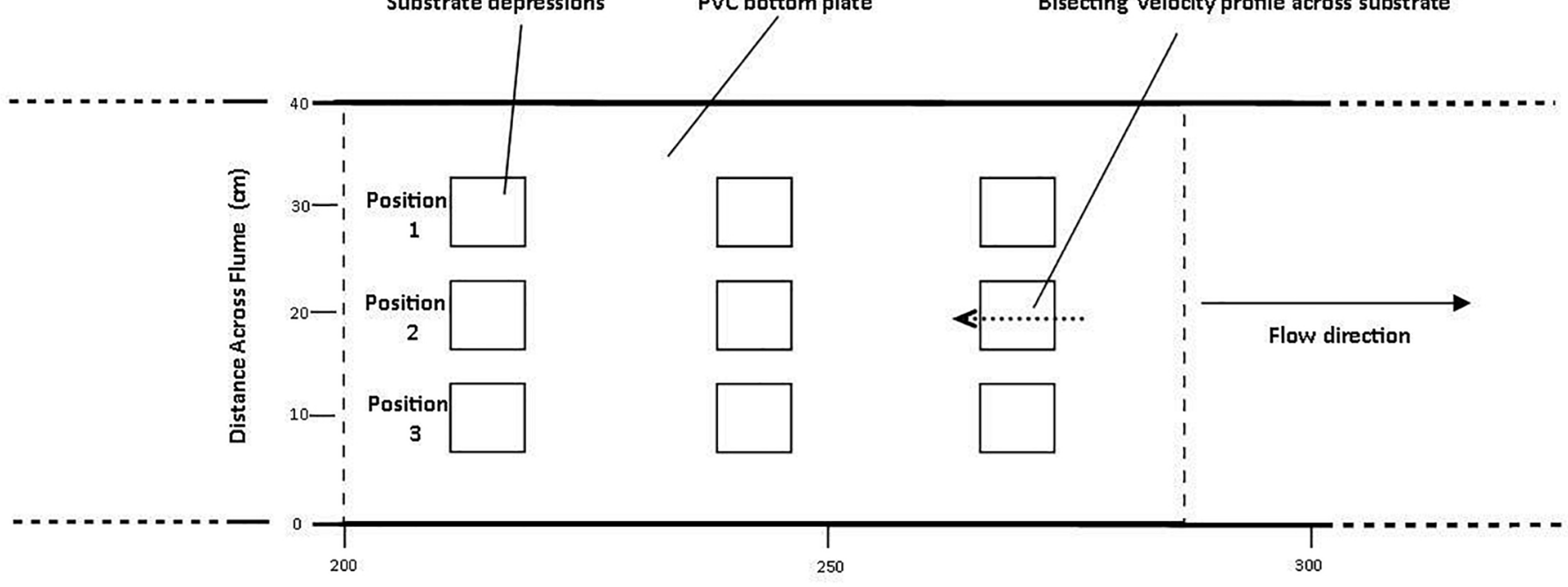

\section{PVC bottom plate}

Bisecting velocity profile across substrate

Distance along flume $(\mathrm{cm})$

Figure 2 


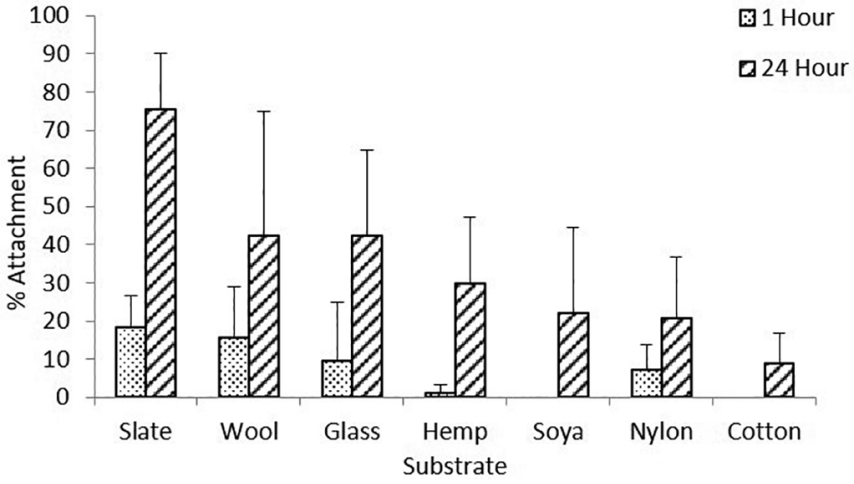

Figure 3 
Wool $\boldsymbol{\nabla}$ Slate Nylon Mesh

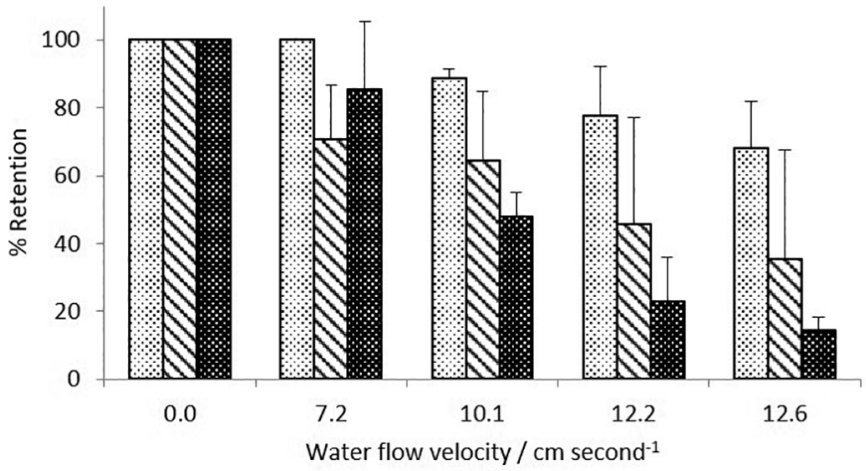

Figure 4 


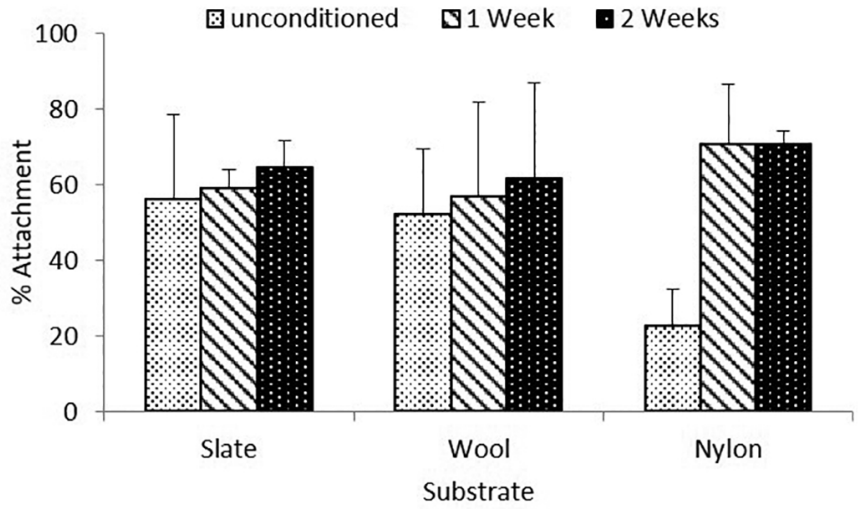

Figure 5 


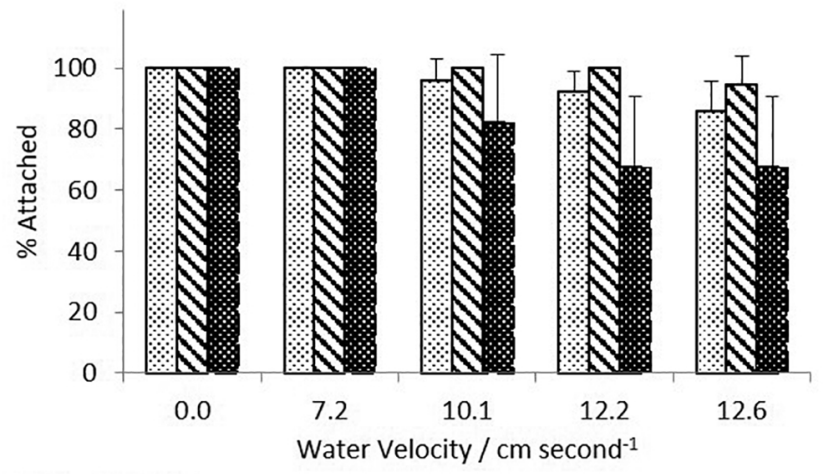

\section{Slate substrate \\ 母Unconditioned $\mathbf{\Delta} 1$ week $\mathbf{2} 2$ weeks}

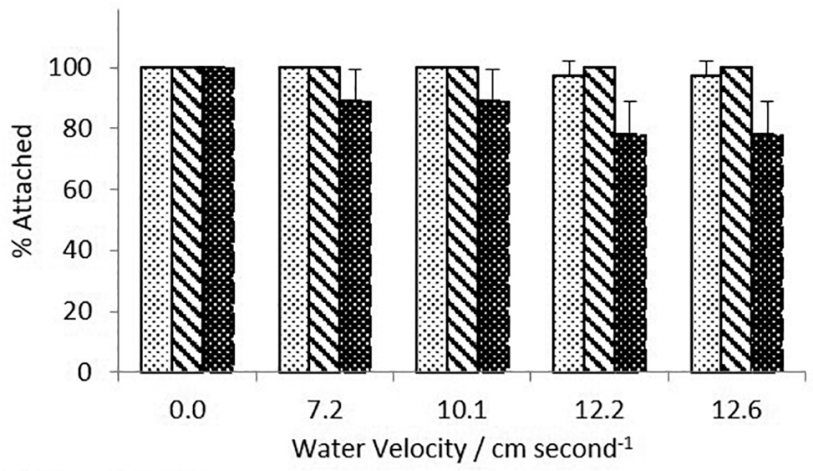

Nylon substrate

๑Unconditioned $\mathbf{8} 1$ week $\mathbf{8} 2$ weeks

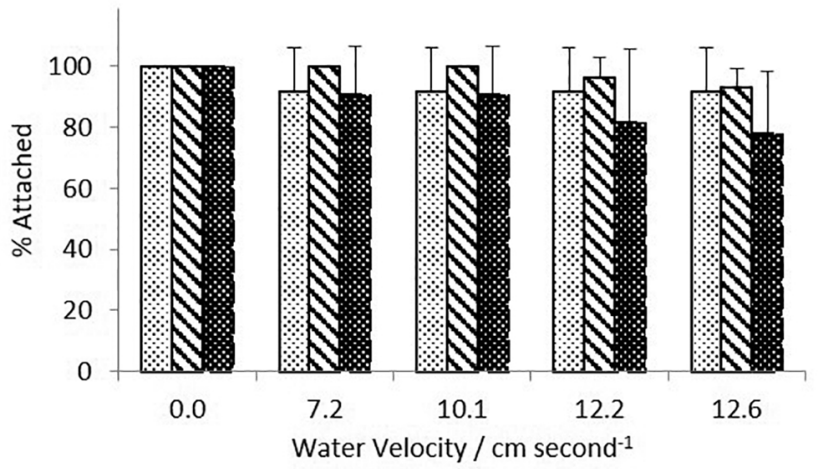

